J. Asiat. Soc. Bangladesh, Sci. 46(1): 1-12, June 2020

\title{
BIOEFFICACY OF THREE INDIGENOUS PLANT EXTRACTS AGAINST CALLOSOBRUCHUS CHINENSIS L. (BRUCHIDAE: COLEOPTERA)
}

\author{
S.M.S. AHMED, M.A. HOSSAIN, A.B. SIDDIQUE AND M. A.A. BACHCHU* \\ Department of Entomology, Hajee Mohammad Danesh Science and Technology \\ University (HSTU), Dinajpur, Bangladesh
}

\begin{abstract}
Results of the evaluation on bioefficacy of three indigenous plant extracts for toxicity and residual effects against the pulse beetle, Callosobruchus chinensis L. (Bruchidae: Coleoptera) showed that the plant extracts had toxic and residual effects for controlling pulse beetle. Mortality and residual effects were statistically different among the plant extracts and doses applied. Neem extract showed the highest adult mortality $(36.78 \%)$ whereas eucalyptus extract showed the lowest $(22.75 \%)$. The order of the toxicity of three plant extracts was found as neem > custard apple > eucalyptus. Mortality was found directly proportional to the hour after treatments which increased with the progress of time. Between two solvents, acetone solvent possessed the highest toxicity (mortality $32.95 \%$ ) but methanol showed the lowest toxicity (mortality $30.56 \%$ ). The residual toxicity was evaluated on the basis of egg laid, adult emergence, seed infestation and weight loss caused by the insect. The highest residual toxicity was found in neem extract with acetone while the lowest in eucalyptus extract with acetone. Neem extract with acetone and custard apple extract with methanol solvent were found effective to toxic and residual effects against pulse beetle of three plant extracts applied.
\end{abstract}

Key words: Bioefficacy, Callosobruchus chinensis, Indigenous plant extracts, Toxicity, Residual effect

\section{Introduction}

Pulse is one of the best sources of plant protein and plays a pivotal role in the diet of common people of developing countries like Bangladesh (Darmadi-Blackberry et al. 2004). The cultivated area of pulse crops in Bangladesh is 10,11,000 acres with annual production of 7,26,000 metric tons (BBS 2016). This amount is not sufficient to meet up the demand. One of the major hindrance to increase the pulse production is the damage of pulse grain from insect infestation in storage. Among the storage insect pests, bruchids are known to cause both quantitative and qualitative losses to pulses. Several species of pulse beetle are reported to attack pulses in storage. Among them Callosobruchus chinensis L. is a major and destructive species which causes up to cent per cent losses of pulses in storage (Bhalla et al. 2008, Jat et al. 2013).

*Corresponding author: adnan_hstu@yahoo.com, adnan@hstu.ac.bd 
The beetles breed rapidly in the storage of the tropical and subtropical environment. $C$. chinensis larvae can easily penetrate into the gram and feed the endosperms resulted the infested grains unsuitable for human consumption; deteriorate nutritional value and loss of seed viability (Deeba et al. 2006). This pest is a serious problem at small farmers' level, village traders and average households where storage conditions are poor and inadequate. The extent of damage varied with different kinds of legumes, duration of exposure time, storage facilities and other factors associated with seeds. Therefore, it is utmost necessary to control this pest. To protect the stored pest, fumigation with synthetic chemicals like methyl bromide and phosphine is an effective method being used only in the warehouses. This technique is expensive to rural farmers, and impractical in the primitive nature of storage in many of the villages (Kim et al. 2003). Synthetic insecticides have been used for a long time with serious drawbacks such as insecticide resistance in pest insects, hazards to human and the environment, destruction of nontarget organism, outbreak of secondary pests and human health hazards (Lee et al. 2001).

Several researchers studied on the insecticidal properties of plant materials (Shukla et al. 2007, Kirubal et al. 2008). These botanical materials can be used as an alternative to synthetic pesticides. Due to several advantages of plant-derived pesticides, like biodegradable, less harmful to environment, non toxic to other animals etc., are becoming popular for the management of insect pests worldwide (Yuya et al. 2009). Although, a number of authors have conducted research on toxicity, repellency, antifeedant activity of botanical pesticides against field and stored grain insects (Bachchu et al. 2003, 2013, Cosimi et al. 2009, Saroukolai et al. 2010, Ghani et al. 2014, Hossain et al. 2014), more investigations are needed to explore the pesticidal properties of indigenous plant materials. Therefore, the present research was undertaken to determine the toxicity and residual effects of three indigenous plant extracts, namely neem, custard apple and eucalyptus on Callosobruchus chinensis in a laboratory condition.

\section{Materials and Methods}

The present experiments were conducted to evaluate the toxicity effects of three indigenous plants extracts against Callosobruchus chinensis in the ambient laboratory conditions $\left(28 \pm 5^{\circ} \mathrm{C}\right.$, and $\left.75 \pm 10 \% \mathrm{RH}\right)$ of the Department of Entomology, Hajee Mohammad Danesh Science and Technology University (HSTU), Dinajpur, Bangladesh during May to August 2017.

Collection and preparation of botanical extracts: The fresh plant leaves of neem (Azadirachta indica), custard apple (Annona reticulata), and eucalyptus (Eucalyptus 
camaldulensis) were collected from the HSTU campus, Dinajpur and surrounding areas. Collected leaves were kept for 7 days in the laboratory for air drying followed by one day sun drying before making powder. They were powdered separately by an electric grinder (Nova Blackberry Blender, AD 999, Bangladesh) in the laboratory and passed through a 60-mesh sieve to get fine powder. For preparation of botanical extracts, $100 \mathrm{gm}$ of each plant powders were mixed separately with $300 \mathrm{ml}$ of acetone and methanol solvents separately in a $500 \mathrm{ml}$ conical flask. Then the mixture was stirred $(600 \mathrm{rpm})$ for 30 minutes and then allowed to shaking in the shaker machine. The mixture was filtered through a filter paper (Whatman no. 1). The solvents were allowed to evaporate by vacuum rotary evaporator (Lab Tech EV311H Rotary Evaporator, China) and finally semi solid crude extracts were obtained. The crude extracts were then preserved in tightly corked vials $(8 \mathrm{ml})$ and stored in a refrigerator $\left(4^{\circ} \mathrm{C}\right)$ for further experimental use.

The insect culture: Healthy gram seeds were collected from the local market of Dinajpur town to culture the insect. They were sterilized and cooled at $8-10 \%$ moisture content level and preserved in a big air tight plastic container for experimental use. Adults of $C$. chinensis were collected from naturally infested gram seeds of the local market of Dinajpur town. The beetles were cultured in separate glass jar $(500 \mathrm{ml})$ with gram seed in ambient laboratory conditions $\left(28 \pm 5^{\circ} \mathrm{C}\right.$, and $\left.75 \pm 10 \% \mathrm{RH}\right)$. Approximately, 200 adults were released in each jar $(500 \mathrm{ml})$ containing $500 \mathrm{gm}$ of seeds. Then the jars were closed with pieces of white muslin cloth and tightly fixed with the help of rubber bands to avoid skip out the beetles. The jars were then left undisturbed for a period of 7 days for oviposition. Then the beetles were separated carefully from the seeds by sieving and seeds along with eggs left undisturbed for emergence of adult. The newly emerged adults were collected and again introduced in new seeds allowed for oviposition in different jars for maintaining stock culture and the stock culture of the test insect was continued during the experimental period. Only 1 to 2 days old adult of $C$. chinensis were used for the experiments purposes.

Toxicity test: To evaluate the direct toxic effect of different botanical extracts against the pulse beetle, different concentrations $(5.0,2.50,1.25,0.625$, and $0.3125 \%)$ along with control treatments were made. One $\mathrm{ml}$ liquid of each dose was dropped separately on Petri dishes $(60 \mathrm{~mm})$ with the help of pipette. Before conducting study, a pilot experiment was done to obtain the appropriate doses (data not shown). Then the plant extracts were covered uniformly the whole area of the Petri dishes. The Petri dishes were air dried for 30 minutes. Control Petri dishes were treated with acetone and methanol solvents only. Two-day-old 10 adult beetles of $C$. chinensis were released in each Petri dish. Three replications were made for each concentration of plant extracts including control 
treatment. The Petri dishes were then kept without food and insect mortality was recorded at 24, 48, and 72 hours after treatments (HATs). The percentage of mortality was corrected using Abbott's formula (Abbott 1987).

$P=\frac{p^{\prime}-C}{100-C} \times 100$

where, $P=$ Percentage of corrected mortality, $P^{\prime}=$ Observed mortality $(\%), \mathrm{C}=$ Mortality $(\%)$ at control.

Residual toxicity test: For residual effect of plant extracts on insect mortality, three different concentrations $(5,2.5$ and $1.25 \%)$ for each plant extract were mixed with gram seed separately ( $1 \mathrm{ml} / 50 \mathrm{~g}$ seed $)$ followed by air dried for 30 minutes. Five pairs one-dayold adult beetles were released into the glass bottle $(250 \mathrm{ml})$ containing plant extracts treated gram seed and bottle was covered with perforated lid. Three replications were maintained for each of the concentration of each plant extracts separately along with control. All treated bottles were kept at ambient room temperature $\left(28 \pm 5^{\circ} \mathrm{C}\right)$ in the laboratory for the oviposition. After 7 days, dead and alive beetles were removed from each container and number of eggs was counted. After emergence, adult beetles and seed holes were counted and recorded. Inhibition rate (\% IR) of adult emergence was calculated by the following formula:

$\% \mathrm{IR}=\mathrm{Cn}-\mathrm{Tn} / \mathrm{Cn} \times 100$ (Shukla et al. 2007).

where, $\mathrm{Cn}=$ Number of insect on control treatment, $\mathrm{Tn}=$ Number of insect on treated treatment.

Statistical analysis: The collected data were statistically analyzed by completely randomized design (CRD) using MSTAT-C statistical software. Before analyzing, the percentage insect mortality was corrected by Abbott's formula. The treatment mean values were adjusted by Duncan's Multiple Range Test (DMRT). The insect mortality data were also subjected to probit analysis.

\section{Results and Discussion}

Direct toxicity of three plant extracts against Callosobruchus chinensis: Insect mortality of three plant extracts differed significantly $(\mathrm{p}<0.05, \mathrm{~F}=603.25, \mathrm{df}=2)$ among the treatments (Table 1). The results indicated that the highest insect mortality was found in the neem extracts $(28.89,38.33$ and $43.11 \%)$ while the lowest in eucalyptus extracts $(15.28,23.89$ and $29.10 \%)$ at 24,48 and 72 HATs, respectively. The insect mortality increased propor-tionally with the time interval. Average adult mortality revealed that the highest mortality was recorded in the neem extract (36.78\%) but the lowest in eucalyptus 
extract $(22.75 \%)$. The insect mortality was significantly $(\mathrm{p}<0.05, \mathrm{~F}=1319.05, \mathrm{df}=5)$ different among all the doses of plant extracts including the control (Table 1). The highest dose (5.0\%) indicated the highest insects mortality (45.00, 60.00 and 65.32\%) and the lowest dose $(0.3125 \%)$ revealed the lowest mortality $(12.78,21.11$ and $26.78 \%)$ at 24, 48, 72 HATs, respectively. The insect mortality was also increased proportionally within time intervals. Average insects mortality of different HATs also indicated that the highest insect mortality $(56.77 \%)$ was found in the maximum dose $(5.0 \%)$ while the lowest $(20.22 \%)$ in the minimum $(0.3125 \%)$ dose. The interaction effects of plant extracts, their doses at different HATs were deferred significantly $(\mathrm{p}<0.05, \mathrm{~F}=26.05$, $\mathrm{df}=$ $10)$ among three plant extracts at different doses where the lowest mortality $(0.16 \%)$ was recorded in untreated control (Table 1$)$. The highest insect mortality $(61.80 \%)$ was found in the neem plant extract followed by custard apple (61.76\%) at the highest doses $(5.00 \%)$ while the lowest $(9.46 \%)$ mortality was found in eucalyptus plant extracts at the lowest dose (0.3125).

The interaction effects of three plant extracts, solvents, doses and times are presented in the Table 2. There was a significant $(\mathrm{p}<0.05, \mathrm{~F}=45.53, \mathrm{df}=10)$ different among the toxicity of the plant extracts when applied against the adult pulse beetle. The percentages of insects mortality at 24, 48 and 72 hours after treatment indicated that the highest mortality (73.60) showed in the neem extracts with acetone solvent at highest dose but eucalyptus extract showed lowest mortality (7.810) at lowest dose. Conversely, custard apple extracts with methanol solvent recorded insect mortality $70.00 \%$ at highest dose while eucalyptus extract with methanol solvent recorded insect mortality $11.11 \%$ at the lowest dose.

The present results agree with other workers. The major active constituent of neem is azadirachtin, which is well known for its antifeedant, toxic and growth regulating effects on insects (Saxena et al. 2004). Azadirachtin ingredient is also active on insects, including stored grain pests, aphids, caterpillars and mealybugs (Morgan 2009). Reports showed that black pepper (Piper nigrum), ceylon cinnamon (Cinnamonnum zealanicum), black cardamom (Amonum subulatum), nutmeg (Myristica fragnans), black cumin (Nigella sativa), turmeric (Curcuma longa) and red pepper (Capsicum frutescens) caused highest mortality of $C$. maculatus (Hossain et al. 2008). Lawati et al. (2002) cited that among the extracts of eight local plants in Oman, seeds of A. squamosa caused the highest mortality of beetles within 24 hours of exposure in methanol extracts. The other extracts that caused high mortality were A. nilotica, C. juncea, M. communis and $S$. aegyptica in methanol and B. saca, J. dhofarica, S. aegyptica and A. indica in ethanol (Hossain et al. 2008). 
Table 1. Mortality of pulse beetle at different HATs (Interaction of plant extracts, doses and times).

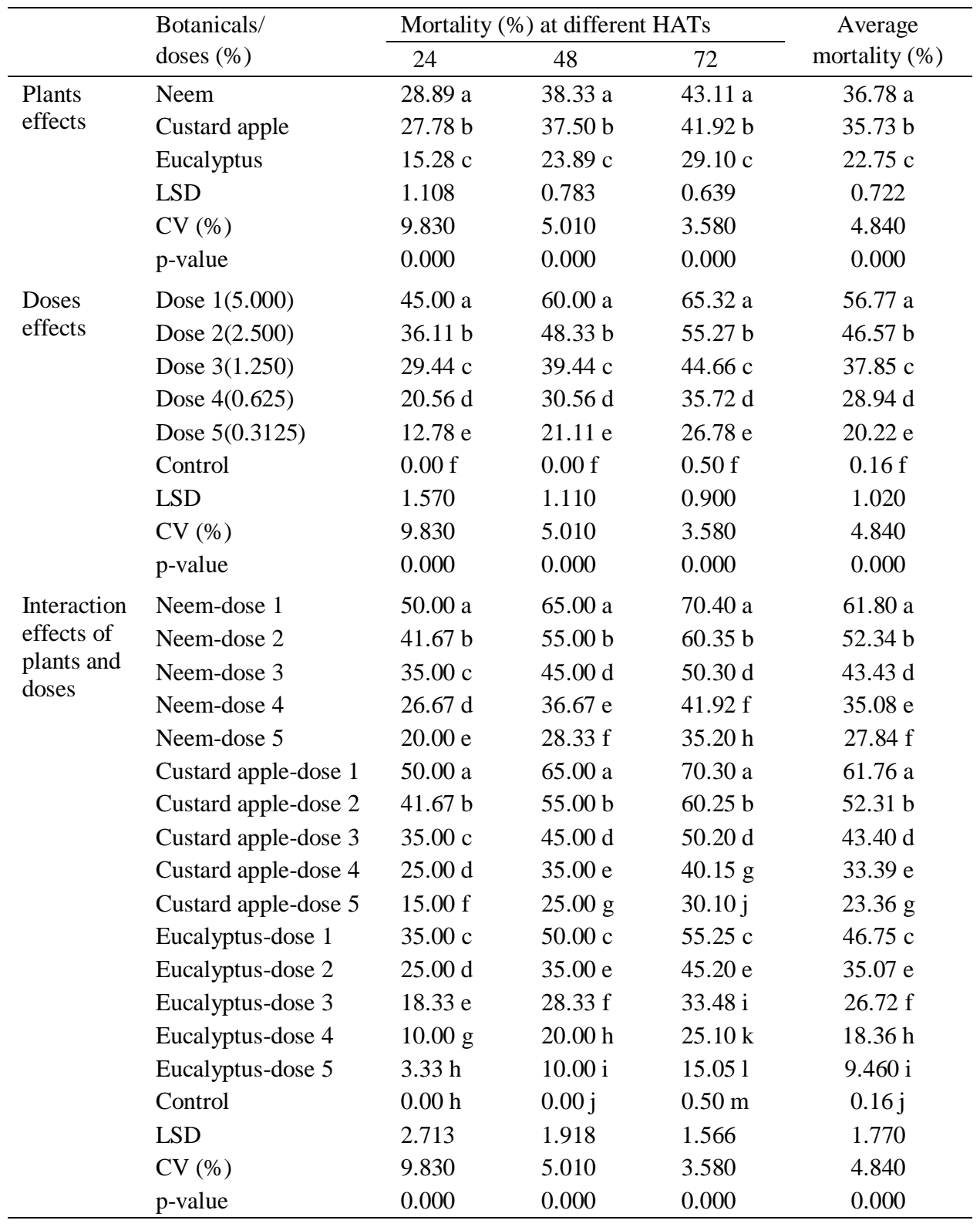

HAT $=$ Hour after treatment, within column values followed by different letter(s) are significantly different by DMRT at $5 \%$ level of probability. 
Bioefficacy of plant extracts against Callosobruchus chinensis

Table 2. Interaction effects of plant extracts and solvents against pulse beetle mortality at different HATs.

\begin{tabular}{|c|c|c|c|c|c|c|}
\hline \multirow{2}{*}{$\begin{array}{l}\text { Name of the } \\
\text { plant extracts }\end{array}$} & \multirow[t]{2}{*}{ Solvents } & \multirow{2}{*}{$\begin{array}{l}\text { Doses } \\
(\%)\end{array}$} & \multicolumn{3}{|c|}{ Mortality (\%) at different HATs } & \multirow{2}{*}{$\begin{array}{l}\text { Average } \\
\text { mortality }(\%)\end{array}$} \\
\hline & & & 24 & 48 & 72 & \\
\hline \multirow[t]{10}{*}{ Neem } & \multirow[t]{5}{*}{ Acetone } & 5.000 & $60.00 \mathrm{a}$ & $80.00 \mathrm{a}$ & $80.80 \mathrm{a}$ & $73.60 \mathrm{a}$ \\
\hline & & 2.500 & $53.33 \mathrm{~b}$ & $70.00 \mathrm{~b}$ & $70.70 \mathrm{~b}$ & $64.68 \mathrm{c}$ \\
\hline & & 1.250 & $50.00 \mathrm{c}$ & $60.00 \mathrm{c}$ & $60.60 \mathrm{c}$ & $56.87 \mathrm{e}$ \\
\hline & & 0.625 & $40.00 \mathrm{~d}$ & $50.00 \mathrm{~d}$ & $50.50 \mathrm{~d}$ & $46.83 \mathrm{~h}$ \\
\hline & & 0.3125 & $30.00 \mathrm{f}$ & $40.00 \mathrm{e}$ & $40.40 \mathrm{e}$ & $36.80 \mathrm{j}$ \\
\hline & \multirow[t]{5}{*}{ Methanol } & 5.000 & $40.00 \mathrm{~d}$ & $50.00 \mathrm{~d}$ & $60.00 \mathrm{c}$ & $50.00 \mathrm{~g}$ \\
\hline & & 2.500 & $30.00 \mathrm{f}$ & $40.00 \mathrm{e}$ & $50.00 \mathrm{~d}$ & $40.00 \mathrm{i}$ \\
\hline & & 1.250 & $20.00 \mathrm{~g}$ & $30.00 \mathrm{f}$ & $40.00 \mathrm{e}$ & 30.001 \\
\hline & & 0.625 & $13.33 \mathrm{~h}$ & $23.33 \mathrm{~h}$ & $33.33 \mathrm{~g}$ & $23.33 n$ \\
\hline & & 0.3125 & $10.00 \mathrm{i}$ & $16.67 \mathrm{j}$ & $30.00 \mathrm{~h}$ & $18.89 \mathrm{p}$ \\
\hline \multirow[t]{10}{*}{ Custard apple } & \multirow[t]{5}{*}{ Acetone } & 5.000 & $40.00 \mathrm{~d}$ & $60.00 \mathrm{c}$ & $60.60 \mathrm{c}$ & $53.53 \mathrm{f}$ \\
\hline & & 2.500 & $33.33 \mathrm{e}$ & $50.00 \mathrm{~d}$ & $50.50 \mathrm{~d}$ & $44.61 \mathrm{~h}$ \\
\hline & & 1.250 & $30.00 \mathrm{f}$ & $40.00 \mathrm{e}$ & $40.40 \mathrm{e}$ & $36.80 \mathrm{j}$ \\
\hline & & 0.625 & $20.00 \mathrm{~g}$ & $30.00 \mathrm{f}$ & $30.30 \mathrm{~h}$ & $26.77 \mathrm{~m}$ \\
\hline & & 0.3125 & $10.00 \mathrm{i}$ & $20.00 \mathrm{i}$ & $20.20 \mathrm{i}$ & $16.73 \mathrm{p}$ \\
\hline & \multirow[t]{5}{*}{ Methanol } & 5.000 & $60.00 \mathrm{a}$ & $70.00 \mathrm{~b}$ & $80.00 \mathrm{a}$ & $70.00 \mathrm{~b}$ \\
\hline & & 2.500 & $50.00 \mathrm{c}$ & $60.00 \mathrm{c}$ & $70.00 \mathrm{~b}$ & $60.00 \mathrm{~d}$ \\
\hline & & 1.250 & $40.00 \mathrm{~d}$ & $50.00 \mathrm{~d}$ & $60.00 \mathrm{c}$ & $50.00 \mathrm{~g}$ \\
\hline & & 0.625 & $30.00 \mathrm{f}$ & $40.00 \mathrm{e}$ & $50.00 \mathrm{~d}$ & $40.00 \mathrm{i}$ \\
\hline & & 0.3125 & $20.00 \mathrm{~g}$ & $30.00 \mathrm{f}$ & $40.00 \mathrm{e}$ & 30.001 \\
\hline \multirow[t]{10}{*}{ Eucalyptus } & \multirow[t]{5}{*}{ Acetone } & 5.000 & $40.00 \mathrm{~d}$ & $50.00 \mathrm{~d}$ & $50.50 \mathrm{~d}$ & $46.83 \mathrm{~h}$ \\
\hline & & 2.500 & $30.00 \mathrm{f}$ & $40.00 \mathrm{e}$ & $40.40 \mathrm{e}$ & $36.80 \mathrm{j}$ \\
\hline & & 1.250 & $20.00 \mathrm{~g}$ & $30.00 \mathrm{f}$ & $30.30 \mathrm{~h}$ & $26.77 \mathrm{~m}$ \\
\hline & & 0.625 & $10.00 \mathrm{i}$ & $20.00 \mathrm{i}$ & $20.20 \mathrm{i}$ & $16.73 \mathrm{p}$ \\
\hline & & 0.3125 & $3.33 \mathrm{~h}$ & $10.00 \mathrm{k}$ & $10.10 \mathrm{j}$ & $7.810 \mathrm{r}$ \\
\hline & \multirow[t]{5}{*}{ Methanol } & 5.000 & $30.00 \mathrm{f}$ & $50.00 \mathrm{~d}$ & $60.00 \mathrm{c}$ & $46.67 \mathrm{~h}$ \\
\hline & & 2.500 & $20.00 \mathrm{~g}$ & $30.00 \mathrm{f}$ & $50.00 \mathrm{~d}$ & $33.33 \mathrm{k}$ \\
\hline & & 1.250 & $16.67 \mathrm{~g}$ & $26.67 \mathrm{~g}$ & $36.67 \mathrm{f}$ & $26.67 \mathrm{~m}$ \\
\hline & & 0.625 & $10.00 \mathrm{i}$ & $20.00 \mathrm{i}$ & $30.00 \mathrm{~h}$ & $20.00 \mathrm{o}$ \\
\hline & & 0.3125 & $3.33 \mathrm{~h}$ & $10.00 \mathrm{k}$ & $20.00 \mathrm{i}$ & $11.11 \mathrm{q}$ \\
\hline Control & & 0.000 & $0.001 \mathrm{j}$ & 0.0011 & $0.001 \mathrm{k}$ & $0.001 \mathrm{~s}$ \\
\hline LSD & & - & 3.837 & 2.713 & 2.215 & 2.503 \\
\hline $\mathrm{CV}(\%)$ & & - & 9.830 & 5.010 & 3.580 & 4.840 \\
\hline
\end{tabular}

HAT $=$ Hour after treatment, within column values followed by different letter(s) are significantly different according to DMRT at 5\% level of probability. 
Probit analysis of direct toxic effect: The $\mathrm{LD}_{50}$ values indicated that neem plant extract $\left(1.72 \mathrm{mg} / \mathrm{cm}^{2}\right)$ with acetone showed the highest toxic effect followed by the custard $(2.42$ $\mathrm{mg} / \mathrm{cm}^{2}$ ) apple with methanol extracts at 24 HAT (Table 3 ). The $\mathrm{LD}_{50}$ values at $48 \mathrm{HAT}$ indicated that neem plant with acetone extracts $\left(0.621 \mathrm{mg} / \mathrm{cm}^{2}\right)$ showed the highest toxic effect followed by the custard apple with methanol solvent $\left(1.248 \mathrm{mg} / \mathrm{cm}^{2}\right)$. Among the three extracts with two solvents, neem plant extract with acetone solvent extracts $(0.37$ $\mathrm{mg}$ ) also performed the highest toxicity as compared with the $\mathrm{LD}_{50}$ values at $72 \mathrm{HAT}$. The Chi-square values were insignificant at $5 \%$ level of probability of different plant extracts at different HATs and mortality data did not show any heterogeneity.

Table 3. Probit mortality of different plant extracts with acetone and methanol solvent against C. chinensis after 24,48 and 72 HATs.

\begin{tabular}{|c|c|c|c|c|c|c|c|c|c|}
\hline \multirow{3}{*}{$\begin{array}{c}\text { Plant extracts } \\
\text { used }\end{array}$} & \multirow{3}{*}{$\begin{array}{c}\text { No. of } \\
\text { insects } \\
\text { used }\end{array}$} & \multicolumn{2}{|c|}{$\begin{array}{c}\mathrm{LD} 50 \\
\left(\mathrm{mg} / \mathrm{cm}^{2}\right)\end{array}$} & \multicolumn{4}{|c|}{$\begin{array}{l}95 \% \text { fiducial } \\
\text { limits }\end{array}$} & \multicolumn{2}{|c|}{$\begin{array}{l}\chi^{2} \text { values } \\
\text { with } 3 \mathrm{df}\end{array}$} \\
\hline & & \multirow{2}{*}{ Acetone } & \multirow{2}{*}{ Methanol } & \multicolumn{2}{|c|}{ Acetone } & \multicolumn{2}{|c|}{ Methanol } & \multirow{2}{*}{ Acetone } & \multirow{2}{*}{$\begin{array}{c}\text { Metha- } \\
\text { nol }\end{array}$} \\
\hline & & & & Lower & Upper & Lower & Upper & & \\
\hline \multicolumn{10}{|c|}{24 HAT } \\
\hline Neem & 30 & 1.717 & 10.036 & 0.812 & 3.631 & 2.647 & 38.043 & 0.220 & 0.089 \\
\hline Custard apple & 30 & 8.679 & 2.470 & 2.187 & 34.435 & 1.319 & 4.626 & 0.712 & 0.016 \\
\hline Eucalyptus & 30 & 6.943 & 17.760 & 3.062 & 15.741 & 3.153 & 100.036 & 0.419 & 0.694 \\
\hline \multicolumn{10}{|c|}{48 HAT } \\
\hline Neem & 30 & 0.621 & 5.348 & 0.321 & 1.202 & 1.860 & 15.373 & 0.019 & 0.032 \\
\hline Custard apple & 30 & 2.470 & 1.248 & 1.319 & 4.626 & 0.718 & 2.171 & 0.016 & 0.013 \\
\hline Eucalyptus & 30 & 4.592 & 6.188 & 2.110 & 9.992 & 2.320 & 16.502 & 0.201 & 0.768 \\
\hline \multicolumn{10}{|c|}{72 HAT } \\
\hline Neem & 30 & 0.372 & 2.343 & 0.177 & 0.7843 & 1.047 & 5.242 & 0.242 & 0.277 \\
\hline Custard apple & 30 & 1.397 & 0.621 & 0.821 & 2.377 & 0.321 & 1.202 & 0.022 & 0.019 \\
\hline Eucalyptus & 30 & 2.732 & 2.569 & 1.478 & 5.049 & 1.359 & 4.856 & 0.082 & 0.082 \\
\hline
\end{tabular}

HAT $=$ Hours after treatment, values were based on five concentrations, three replications of 10 insects each. $\chi^{2}=$ Goodness of fit, Tabulated values of $\chi^{2}=12.838$ with $3 \mathrm{df}$ at $5 \%$ level of probability.

It was observed that all the plant extracts were more or less effective for controlling the pulse beetle but neem extract with acetone solvent was the most effective followed by the custard apple and eucalyptus plant extracts with acetone solvent (Table 3). The custard apple plant extracts with methanol solvent showed the highest effect followed by the neem and eucalyptus plant extracts against the pulse beetle. The results agree with other workers. They reported that acetone extract of botanicals significantly reduced the adult population of C. chinensis (Dwivedi and Kumari 2000 and Dwivedi and Venugopalan 2001). From the above results it was concluded that acetone extract of neem and custard apple of methanol was effective for controlling the pulse beetle. The present result agree 
with the findings of Mamun et al. (2009) who reported that acetone extract of neem seed showed highest toxicity against stored grain pest. Rahman and Talukder (2004), reported that the different plant/weed derivatives the development of the pulse beetles, $C$. maculatus (Coleoptera: Bruchidae) feed on black gram, Vinga mungo seeds. Plant extracts, powder, ash and oil from several plant materials inhibited oviposition of pulse

Table 4. Residual toxicity effect of plant extracts against pulse beetle egg laid, adult emergence, seeds infestation and weight loss.

\begin{tabular}{|c|c|c|c|c|c|c|}
\hline Solvents & $\begin{array}{c}\text { Plant } \\
\text { extracts }\end{array}$ & $\begin{array}{c}\text { Doses } \\
(\%)\end{array}$ & $\begin{array}{l}\text { Inhibition } \\
\text { of egg laid } \\
(\%)\end{array}$ & $\begin{array}{l}\text { Inhibition rate } \\
\text { of adult } \\
\text { emergence }(\%)\end{array}$ & $\begin{array}{c}\text { Inhibition of } \\
\text { seed } \\
\text { infestation }(\%)\end{array}$ & $\begin{array}{l}\text { Weight } \\
\text { loss } \\
(\%)\end{array}$ \\
\hline \multirow{8}{*}{ Acetone } & \multirow{3}{*}{ Neem } & 5.00 & $84.89 \mathrm{~d}$ & $87.38 \mathrm{~d}$ & $88.03 \mathrm{~d}$ & $95.00 \mathrm{~b}$ \\
\hline & & 2.50 & $82.10 \mathrm{e}$ & $84.88 \mathrm{e}$ & $86.55 \mathrm{e}$ & $94.40 \mathrm{~d}$ \\
\hline & & 1.25 & $79.11 \mathrm{f}$ & $80.60 \mathrm{f}$ & $82.34 \mathrm{f}$ & $94.00 \mathrm{e}$ \\
\hline & \multirow{4}{*}{$\begin{array}{l}\text { Custard } \\
\text { apple }\end{array}$} & 5.00 & $75.88 \mathrm{~h}$ & $75.95 \mathrm{~g}$ & $76.42 \mathrm{~h}$ & $92.60 \mathrm{f}$ \\
\hline & & 2.50 & $72.56 \mathrm{j}$ & $72.97 \mathrm{i}$ & $73.33 \mathrm{j}$ & $92.20 \mathrm{~g}$ \\
\hline & & 1.25 & 68.111 & $69.52 \mathrm{j}$ & 69.881 & $92.00 \mathrm{~h}$ \\
\hline & & 5.00 & $63.78 \mathrm{n}$ & $65.83 \mathrm{~m}$ & $65.80 n$ & $90.60 \mathrm{j}$ \\
\hline & \multirow[t]{3}{*}{ Eucalyptus } & 2.50 & $58.89 \mathrm{q}$ & $58.81 \mathrm{p}$ & $58.27 \mathrm{q}$ & $90.20 \mathrm{k}$ \\
\hline \multirow{10}{*}{ Methanol } & & 1.25 & $54.67 \mathrm{r}$ & $52.97 \mathrm{q}$ & $53.58 \mathrm{r}$ & 90.001 \\
\hline & & 5.00 & $76.67 \mathrm{~g}$ & $76.24 \mathrm{~g}$ & $78.61 \mathrm{~g}$ & $91.00 \mathrm{i}$ \\
\hline & \multirow[t]{2}{*}{ Neem } & 2.50 & $73.58 \mathrm{i}$ & $73.68 \mathrm{~h}$ & $75.41 \mathrm{i}$ & $90.60 \mathrm{j}$ \\
\hline & & 1.25 & $69.17 \mathrm{k}$ & $68.80 \mathrm{k}$ & $70.56 \mathrm{k}$ & $90.20 \mathrm{k}$ \\
\hline & \multirow{4}{*}{ Custard apple } & 5.00 & $90.83 \mathrm{a}$ & $91.62 \mathrm{a}$ & $92.64 \mathrm{a}$ & $96.00 \mathrm{a}$ \\
\hline & & 2.50 & $88.67 \mathrm{~b}$ & $90.26 \mathrm{~b}$ & $91.26 \mathrm{~b}$ & $95.00 \mathrm{~b}$ \\
\hline & & 1.25 & $86.17 \mathrm{c}$ & $88.89 \mathrm{c}$ & $90.04 \mathrm{c}$ & $94.60 \mathrm{c}$ \\
\hline & & 5.00 & $66.75 \mathrm{~m}$ & 66.711 & $66.75 \mathrm{~m}$ & $89.20 \mathrm{~m}$ \\
\hline & \multirow[t]{2}{*}{ Eucalyptus } & 2.50 & 61.83 o & $62.65 n$ & 61.99 o & $88.60 n$ \\
\hline & & 1.25 & $59.42 \mathrm{p}$ & 59.92 о & $59.74 \mathrm{p}$ & $88.20 \mathrm{o}$ \\
\hline LSD & & 0.700 & 0.505 & 0.016 & 0.471 & 0.700 \\
\hline $\mathrm{CV} \%$ & & 0.570 & 0.410 & 0.000 & 0.390 & 0.570 \\
\hline
\end{tabular}

$\mathrm{IR}=$ Inhibition rate, within column values followed by different letter(s) are significantly different by DMRT at $5 \%$ level of probability.

beetle. Other researcher reported that the oviposition of pulse beetle markedly reduced when stored seeds were treated with different botanical extracts like neem, jatropha, sweetsop and bishkatali (AL-Lawati et al. 2002 and Mollah and Islam 2002). It is reported that acetone extract of botanicals significantly reduced the adult population of $C$. chinensis (Dwivedi and Kumari 2000 and Dwivedi and Venugopalan 2001). Sathyaseelan 
et al. (2008) also cited that some kinds of botanicals with ethanol extracts reduced the adult emergence of $C$. chinensis in green gram seeds.

Residual toxicity of three plant extracts against pulse beetle: The results of residual toxic effects of neem, custard apple and eucalyptus plant extracts on $C$. chinensis are presented in Table 4. The highest inhibition of egg laid (90.83\%) was calculated at 5.0\% in custard apple with methanol solvent while the lowest $(54.67 \%)$ in eucalyptus with acetone extracts at $1.25 \%$. The highest inhibition of adult emergence $(91.62 \%)$ and seed infestation (92.64\%) was also recorded in custard apple at highest dose but the lowest inhibition of adult emergence (52.97\%) and seed infestation (53.58\%) in eucalyptus with acetone solvent extracts at lowest doses $(1.25 \%)$. The highest of weight loss $(96 \%)$ was also found in custard apple with methanol extract.

From the present study it is clear that the botanical plant extracts of neem, custard apple and eucalyptus extracts used as pesticides have a great economic and environmental importance. Among the three botanical extracts with two solvents, neem extracts with acetone solvent and custard apple extracts with methanol solvent showed the highest toxic and residual effect against pulse beetle. The findings of the present investigation revealed the broad spectrum toxic properties of neem, custard apple and eucalyptus extracts against the adult of pulse beetle.

\section{References}

Abbott, W.S. 1987. A method of computing the effectiveness of an insecticide. J. American Mosq. Cont. Assoc. 3: 302-303.

Al-Lawati, I.L.L., K.M. Aain, and M. Deadman. 2002. Potential of Omani flora as source of natural products icr control of pulse beetle. Callosobruchus chinensis. Sultan Qaboos University. J. Res. Agric. Sci. 7(1): 59-61.

Bachchu, M.A.A.., M.A. Sardar and M.Z.A. Pramanik. 2003. Integrated control of pulse beetle, Callosobruchus chinensis Linn. in protection of green gram seeds. Bangladesh J. Seed Sci. Tech. 1(2): 85-89.

Bachchu, M.A.A., M.O. Ghani, M.A. Hossain and R. Ara. 2013. Insecticidal and repellent effect of some indigenous plant extracts against rice weevil, Sitophilus oryzae (L.) (Coleoptera: Curculionidae). Bangladesh J. Entomol. 23(2): 97-114.

BBS (Bangladesh Bureau of Statistics). 2016. Statistical Pocket Book of Bangladesh (27 edition), Statistics Division, Ministry of Planning, Govt. of the People's Republic of Bangladesh, pp. 97-114.

Bhalla, S., K. Gupta, B. Lal, M.L. Kapur and R.K. Khetrapal. 2008. Efficacy of various nonchemical methods against pulse beetle, Callosobrachus maculatus (F.). ENDURE International Conference, Diversifying Crop Protection, France. pp. 1-4.

Cosimi, S., E. Rossi, P.L. Cioni and A. Canale. 2009. Bioactivity and qualitative analysis of some essential oils from mediterranean plants against stored-product pests: evaluation of repellency against Sitophilus zeamais, Cryptolestes ferrugineus (Stephens) and Tenebrio molitor (L.). J. Stored Prod. Res. 45: 125-132. 
Bioefficacy of plant extracts against Callosobruchus chinensis

Darmadi-Blackberry, I., M.L. Wahlqvist, A. Kouris-Blazos., B. Steen, W. Lukito, Y. Horie and K. Horie. 2004. Legumes: The most important dietary predictor of survival in older people of different ethnicities. Asia Pacific J. Clin. Nature 13(2): 217-20.

Deeba, F., M. Sarwar and R.D. Khuhro. 2006. Varietal susceptibility of mungbean genotypes to pulse beetle, Callosobruchus analis (Fabricius) (Coleoptera : Bruchidae). Pakistan J. Zool. 38: 265-268.

Dwivedi, S.C. and A. Kumari. 2000. Efficacy of Ipomoea palmata as ovipositional deterrent, ovicide and repellent against pulse beetle, Callosobruchus chinensis (L.). Uttar Pradesh. J. Zool. 20(3): 205-208.

Dwivedi, S.C. and S. Venugopalan. 2001. Evaluation of leaf extracts for their ovicidal action against Callosobruchus chinensis (L.). Asian J. Exp. Sci. 16(1\&2): 29-34.

Ghani, M.O., M.A.A. Bachchu, M.A. Hossain and R. Ara. 2014. Bioefficacy of some indigenous plant extracts against rice weevil, Sitophilus oryzae (L.). Stored J. Sci. Tech. 12: 26-34.

Hossain, M.A., M.A.A. Bachchu, K.S. Ahmed and M.A. Haque. 2014. Effectiveness of indigenous plant powders as grain protectant against Callosobruchus chinensis (L.) in stored chickpea (Cicer arietinum). Bangladesh J. Agril. Res. 39(1): 93-103.

Hossain, S., A. Mahadi and M.K. Rahman. 2008. Insecticidal effect of some species on Callosobruchus maculaus (Fabricius) in black gram seeds. University J. Zool. Rajshahi 27: 47-50.

Jat, N.R., B.S. Rana and S.K. Jat. 2013. Estimation of losses due to pulse beetle in chickpea. The Bioscan. 8: 861-863.

Kim, S.I., C. Park, M.H. Ohh, H.C. Cho and Y.J. Ahn. 2003. Contact and fumigant activities of aromatic plant extracts and essential oils against Lasioderma serricorne (Coleoptera: Anobiidae). J. Stored Prod. Res. 39: 11-19.

Kirubal, S., B.P. Mishra, I.S. Stalin and S. Jeeva. 2008. Traditional pest management practices in Kanyakumari district, southern peninsular India. Indian J. Trad. Knowl. 5(1): 71-74.

Lawati, H.T., K.M. Al-Azam, and M.L. Deadman. 2002. Insecticidal and repellent properties of subtropical plant extracts against pulse beetle, Callosobruchus chinensis (Coleoptera Bruchidae). Agril. Sci. 7(1): 37-45.

Lee, B., W. Choi, S. Lee, and B. Park. 2001. Fumigant toxicity of essential oils and their constituent compounds towards the rice weevil, Sitophilus oryzae. Crop Prot. 20: 317-320.

Mamun, M.S.A., M. Shahjahan and M. Ahmad. 2009. Laboratory evaluation of some indigenous plant extracts against red flour beetle, Tribolium castaneum Herbst. J. Bangladesh Agril. Univ. 7(1): $1-5$.

Mollah, J.U. and W. Islam. 2002. Effect of Polygonum hydropiper L. extracts on the oviposition and egg viability of Callosobruchus maculatus F. (Coleopetra: Bruchidae). J. Bio. Sci. 10: $113-116$

Morgan, E.D. 2009. Azadirachtin, a scientific gold mine, Bioorganic and Medicinal Chemistry. 17(12): 4096-4105.

Rahman, A. and F.A. Talukder. 2004. Bio-efficacy of some plant derivatives that protect grain against the pulse beetle, Callosobruchus maculatus. J. Insect Sci. 6(3): 1-10.

Saroukolai, A.T., S. Moharramipour and M.H. Meshkatalsadat. 2010. Insecticidal properties of Thymus persicus essential oil against Tribolium castaneum and Sitophilus oryzae. J. Pest Sci. 83: 3-8.

Sathyaseelan, V., V. Baskaran and S. Mohan. 2008. Efficacy of some indigenous pesticidal plants against pulse beetle, Callosobruchus maculatus (L.) on green gram. J. Entomol. 5(2): 128-132.

Saxena, J., G. Georg, L. Orphae and D. Pauline. 2004. A study on the use of indigenous technological knowledge (ITK) for rice pest management in Assam. Insect Environ. 8(1): 9499. 
Shukla, R., B. Srivastava, R. Kumar and N.K. Dubey. 2007. Potential of some botanical powders in reducing infestation of chickpea by Callosobruchus chinensis, Coleoptera : Bruchidae. J. Agri. Technol. 3(1): 11-19.

Yuya, A.I., A. Tadesse, F. Azerefegne, and T. Tefera. 2009. Efficacy of combining Niger seed oil with malathion $5 \%$ dust formulation on maize against the maize weevil, Sitophilus zeamais (Coleoptera : Curculionidae). J. Stored Prod. Res. 45: 67-70.

(Revised copy received on 13.01.2020) 